\title{
Importance of predation by groundfish, marine mammals and birds on walleye pollock Theragra chalcogramma and Pacific herring Clupea pallasi in the eastern Bering Sea
}

\author{
P. A. Livingston \\ Alaska Fisheries Science Center, National Marine Fisheries Service, National Oceanic and Atmospheric Administration, \\ 7600 Sand Point Way NE, BIN C15700, Seattle, Washington 98115-0070, USA
}

\begin{abstract}
Consumption of walleye pollock Theragra chalcogramma and Pacific herring Clupea pallasi by groundfish predators in the eastern Bering Sea was quantified and described using data obtained in 1985-88. Groundfish predators considered here include walleye pollock Theragra chalcogramma; Pacific cod Gadus macrocephalus; yellowfin sole Pleuronectes asper; flathead sole Hippoglossoides elassodon; rock sole Pleuronectes bilineatus; Alaska plaice Pleuronectes quadrituberculatus; arrowtooth flounder Atheresthes stomias; and Greenland turbot Reinhardtius hippoglossoides. Marine manmal and bird consumption of pollock and herring was estimated for 1985 and compared with groundfish consumption. Groundfish predation on pollock during this time period was dominated by cannibalism on age-0 pollock by adult pollock. The highest predation rate occurred in 1985 when the largest pollock year class, as assessed at age 1, during the time period was produced. Predation mortality estimates by age on the 1985 year class were higher than adjacent year classes. Apparently, predators responded to the increased abundance of the 1985 pollock year class by switching to predation on that year class. The impact of this predation appeared to dampen the size of the 1985 year class at age 3 relative to other adjacent year classes. Marine mammal and bird predation on pollock was small relative to pollock cannibalism. However, marine mammal predation on older pollock was more important, almost doubling the estimated predation mortality rate of age-2 fish. Herring consumption by groundfish predators tended to be sporadic in time and space and may have depended on encounter rates of herring schools rather than overall biomass. Pacific cod was the most consistent groundfish predator on herring. There was no apparent relationship between biomass of herring consumed by groundfish predators and cohort analysis estimates of herring biomass in a given year, suggesting no density-dependent predator response. Marine mammal and bird predation on herring was approximately the same as that by groundfish in terms of weight and about half in terms of numbers. Total predation removals of herring were not large relative to exploitable stock size, indicating that predation of juvenile herring, at least during summer periods typically sampled, was not an important source of herring mortality.
\end{abstract}

KEY WORDS: Groundfish predation · Marine birds · Marine mammals

\section{INTRODUCTION}

Walleye pollock Theragra chalcogramma and Pacific herring Clupea pallasi are prey to some marine fish, birds, and mammals in the eastern Bering Sea (Hunt et al. 1981, Lowry \& Frost 1985, Livingston et al. 1986, Dwyer et al. 1987). Pollock, in particular, has been a major food item in the diets of most of these predators during certain study periods, which typically lasted 1 to 2 yr. However, the abundance trends of pollock and Pacific herring in the eastern Bering Sea over the last 25 to 30 yr have been cyclic in nature, with the biomass of each species showing 2 major periods of increase and decrease (Wespestad 1991, Wespestad \& Dawson 1991) (Fig. 1). Furthermore, the recruitment of particular year classes has fluctuated even more widely from year to year (Fig. 2). With the exception of northern fur seals Callorhinus ursinus during the $1960-74$ period, 
little effort has been devoted to studying the changes in diet composition of predators of pollock and herring over long periods of time that would include one or more cycles of prey abundance. Even in the fur seal data time series, samples were obtained somewhat opportunistically, sampling areas and times were not always consistent across years, and little attention was paid to size or age of prey consumed.

It is important to know the magnitude of predation mortality at each age inflicted on important fish populations by fish, mammals and birds to better understand where competitive interactions might be highest and to better assess the importance of predation mortality in the population dynamics of the prey population. Because there are no sampling programs that determine the abundance of important prey populations such as juvenile walleye pollock, it is difficult to compare the amount eaten by a predator to the total amount of prey available. Similarly, estimates of Pacific herring abundance are available only for the spawning portion of the population arriving at inshore spawning grounds. Thus, we are limited to comparing amounts of prey eaten by predators to prey abundance estimates at older ages when they become vulnerable to adult

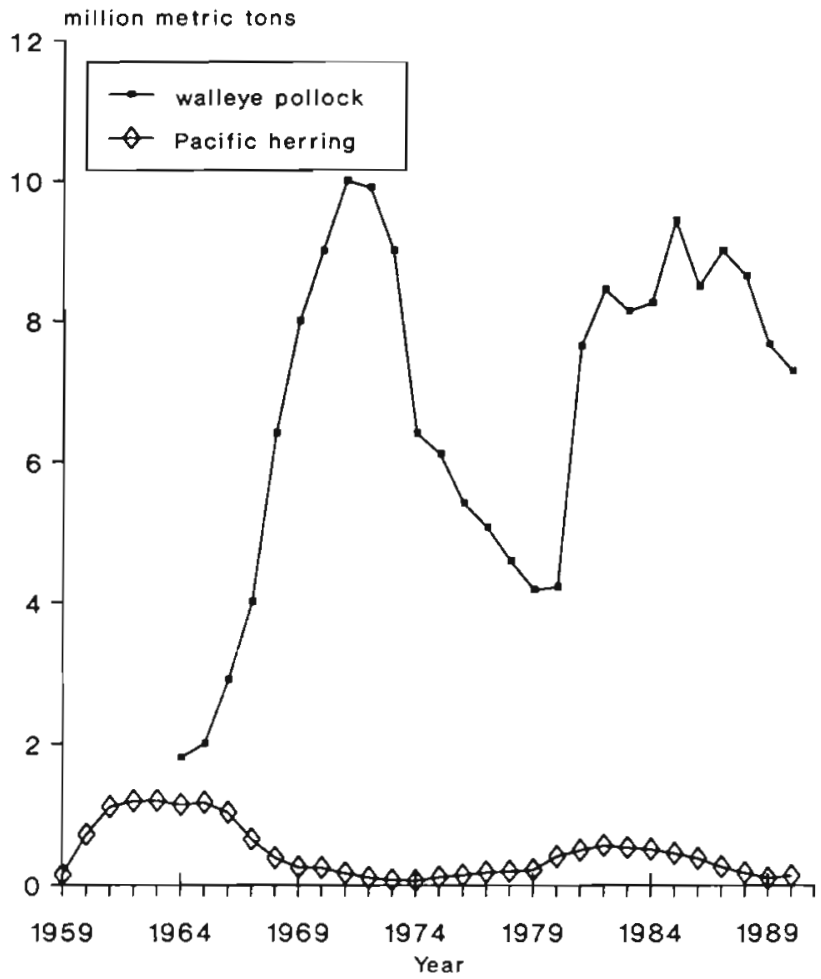

Fig. 1. Theragra chalcogramma and Clupea pallasi. Cohort analysis estimates of total exploitable biomass of walleye pollock and Pacific herring in the eastern Bering Sea from 1959 to 1990 (from Wespestad 1991, Wespestad \& Dawson 1991)

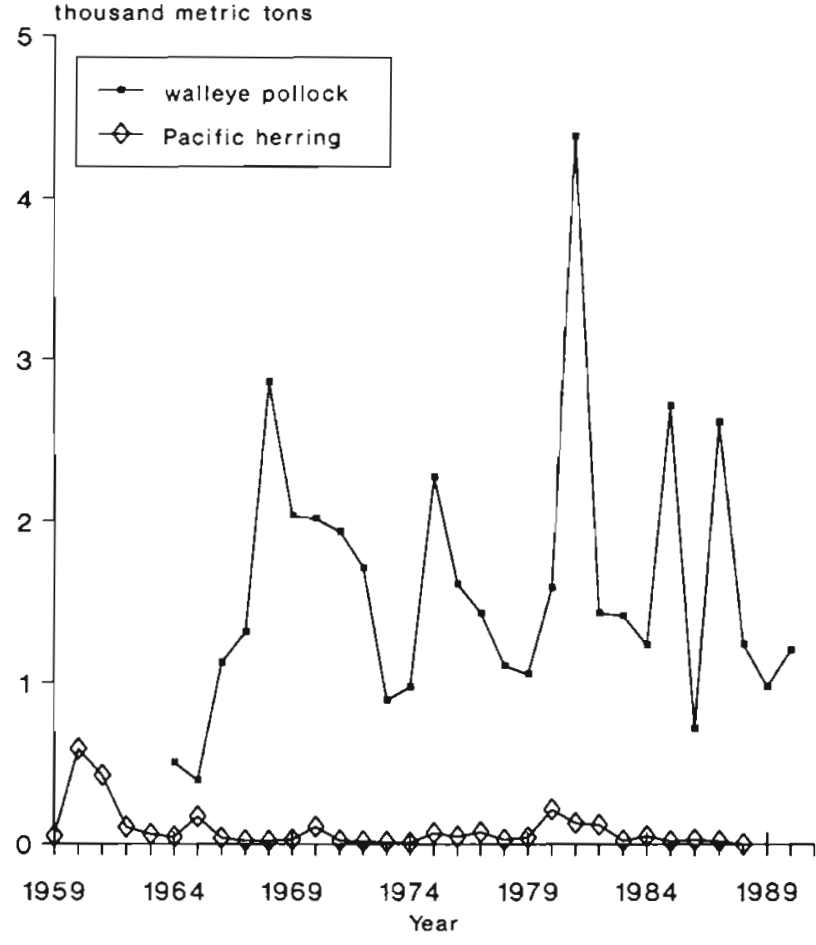

Fig. 2. Theragra chalcogramma and Clupea pallasi. Cohort analysis estimates of year class biomass at age 3 of walleye pollock, and Pacific herring in the eastern Bering Sea from 1959 to 1990 (from Wespestad 1991. Wespestad \& Dawson 1991)

surveys. Also, we must make inferences about mortality rates of juveniles to reconstruct juvenile population abundance.

It becomes especially important to know the relative magnitude of predation at age inflicted by fish, mammals and birds on a prey population when commercial fisheries are also removing part of the prey population. We need to know the amount and size of prey that are removed by natural predators compared to the amount and size of prey that are removed by a fishery before we can speculate on the impact of fishery removals on a predator's prey base. Simply because predators and fisheries target the same species does not necessarily imply they are competing for the same portion of the resource. For example, Livingston (1989) showed the competitive interaction between pollock fisheries in the eastern Bering Sea and northern fur seals was minimal because the latter ate primarily age- 0 and age-1 pollock, while fisheries took mainly age- 3 and older pollock. Because the fishery took older, cannibalistic pollock, the short-term effect of the fishery was to enhance survival of age-0 pollock. Thus, as long as the level of fishing effort did not affect recruitment into the juvenile population, the fishery appeared to benefit northern fur seals. The same logic would also apply to 
marine birds in the eastern Bering Sea that rely on juvenile pollock for food.

This paper aims to examine groundfish predation on walleye pollock and Pacific herring because of the importance of these 2 prey not only to groundfish, but also to other predators such as marine mammals, birds, and the commercial fishery. The total amount of pollock and herring consumed by groundfish predators was estimated for a series of years (1985 to 1988) where food habits data were available. Predation on pollock and herring by groundfish was compared to existing data on removals by mammals, birds, and the commercial fishery.

\section{METHODS}

Groundfish data. Stomachs were collected from major groundfish species primarily during May through September from 1985 to 1988 (Table 1) on the eastern Bering Sea shelf. Contents were analyzed in the laboratory. Emphasis was placed on the identification and measurement of fish and crab prey by species. A detailed description of the laboratory methods used for the stomach analyses can be found in Livingston $(1989,1991)$.

Diet composition in terms of percent by weight was calculated for each predator's $10 \mathrm{~cm}$ size group interval. The stomach content data for each groundfish predator were then subjectively lumped into appropriate predator length groups based on similarity in percent by weight of main prey items in adjacent size groups. The proportion by weight $(P)$ of walleye pollock and Pacific herring in the diet of each predator size group within each major stratum of the eastern Bering Sea shelf (Fig. 3) was then estimated. These data were combined with estimates of predator population biomass $(B$, metric tonnes) and daily ration $(D R=$ fraction of body weight consumed daily) to calculate the total amount of pollock and herring consumed by each groundfish predator population in a stratum using the following equation:

$$
C_{i}=D R_{i} \cdot D \cdot B_{i} \cdot P_{i}
$$

where $C_{2}=$ consumption in tonnes of a prey species by predator size group $i_{i}$ and $D=$ number of days in the sampling period when the prey species was vulnerable to predation.

Table 1. Number of groundfish stomachs sampled in the eastern Bering Sea in May-September 1985 to 1988. (Walleye pollock samples taken from October to December are shown in parentheses)

\begin{tabular}{|c|c|c|c|c|}
\hline Species & 1985 & 1986 & 1987 & 1988 \\
\hline $\begin{array}{l}\text { Walleye pollock } \\
\text { Theragra chalcogramma }\end{array}$ & $\begin{array}{r}970 \\
(589)\end{array}$ & $\begin{array}{l}2164 \\
(574)\end{array}$ & $\begin{array}{r}1599 \\
(0)\end{array}$ & $\begin{array}{r}1485 \\
(29)\end{array}$ \\
\hline $\begin{array}{l}\text { Pacific cod } \\
\text { Gadus macrocephalus }\end{array}$ & 1721 & 1938 & 978 & 798 \\
\hline $\begin{array}{l}\text { Yellowfin sole } \\
\text { Pleuronectes asper }\end{array}$ & 1142 & 1630 & 1660 & 1126 \\
\hline $\begin{array}{l}\text { Flathead sole } \\
\text { Hippoglossoides elassodon }\end{array}$ & 940 & 938 & 654 & 541 \\
\hline $\begin{array}{l}\text { Rock sole } \\
\text { Pleuronectes bilineatus }\end{array}$ & 0 & 0 & 224 & 209 \\
\hline $\begin{array}{l}\text { Alaska plaice } \\
\text { Pleuronectes quadrituberculatus }\end{array}$ & 0 & 0 & 174 & 114 \\
\hline $\begin{array}{l}\text { Arrowtooth flounder } \\
\text { Atheresthes stomias }\end{array}$ & 496 & 600 & 411 & 337 \\
\hline $\begin{array}{l}\text { Greenland turbot } \\
\text { Reinhardtius hippoglossoides }\end{array}$ & 306 & 71 & 75 & 314 \\
\hline Total & 6164 & 7915 & 5775 & 4953 \\
\hline
\end{tabular}

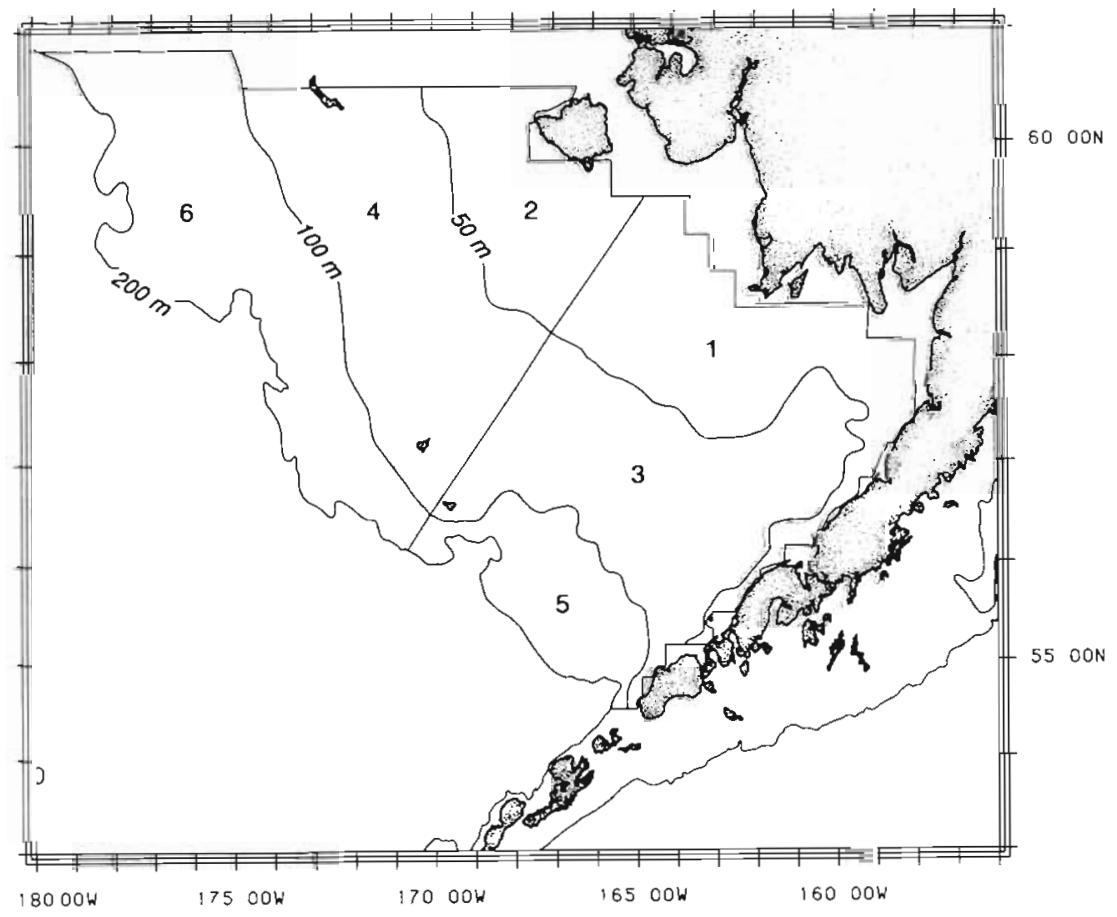

Fig. 3. The eastern Bering Sea shelf showing bottom depth zones and groundfish sampling strata 
Table 2. Estimated total biomass of key groundfish predators in the eastern Bering Sea for 1985 to 1988. Walleye pollock and yellowfin sole biomass estimates are from cohort analysis and the remaining estimates are derived from. Alaska Fisheries Science Center bottom trawl surveys

\begin{tabular}{|lrrrr|}
\hline Predator & \multicolumn{4}{c}{ Biomass $\left(\mathrm{t} \times 10^{3}\right)$} \\
& 1985 & 1986 & 1987 & 1988 \\
\hline Walleye pollock & 9964 & 10180 & 9801 & 9293 \\
Pacific cod & 961 & 1134 & 1142 & 959 \\
Yellowfin sole & 3015 & 2768 & 2675 & 2656 \\
Flathead sole & 333 & 369 & 406 & 557 \\
Rock sole & - & - & 1249 & 1903 \\
Arrowtooth flounder & 164 & 232 & 291 & 306 \\
Greenland turbot & 8 & 6 & 11 & 12 \\
Total & 14445 & 14689 & 15575 & 15686 \\
& \multicolumn{5}{c}{1985 and } \\
a Rock sole stomachs were not sampled during \\
1986
\end{tabular}

Daily ration $(D R)$ estimates were taken from Livingston (1991). Rations were estimated using known annual fish growth increments and assuming gross conversion efficiency rates of food to somatic tissue to be $25 \%$ for juvenile fish and $10 \%$ for adult fish based on estimates presented by Brett \& Groves (1979). The time period of analysis $(D)$ for total consumption estimates by all groundfish predator species except walleye pollock was May through September, or $153 \mathrm{~d}$. The analysis was restricted to this time period because most stomach samples are collected during this period and survey estimates of groundfish biomass are obtained at this time. Total consumption estimates for predatory pollock were made for May through December since there were pollock stomach content data available from this time period.

Predator biomass estimates $(B)$ (Table 2) for all species except pollock and yellowfin sole Pleuronectes asper were obtained from summer bottom trawl surveys of the eastern Bering Sea shelf. These surveys do not provide good biomass estimates of adult yellowfin sole or the semipelagic pollock. Therefore, cohort analysis estimates of Bakkala \& Wilderbuer (1990) and Wespestad et al. (1990) were used.

Total consumption estimates in terms of biomass were converted to numbers using the size frequency of a prey in the stomach contents of a given predator size group by stratum and year along with the lengthweight relationship for the prey. If no prey size information was available in a stratum for a given predator size group, then the prey size frequency over all strata for that predator size group was used. Biomass was not converted to numbers if no prey size frequency information was available for a predator size group.

Marine mammal and bird data. Available data in the literature (listed below) on marine mammal and bird population size, diet, and energetic requirements were used to calculate the total amount of pollock and herring consumed by these groups. Because 1985 was the only year during the 1985 to 1988 period where substantial marine mammal diet information was available, it was chosen as the year for comparing the magnitude of pollock and herring consumption between fish predators and mammal and bird predators. Only predation by pinnipeds was included in the marine mammal consumption estimates because virtually no quantitative data on the diet of cetaceans was available.

Pinniped species included in the analysis were northern fur seal Callorhinus ursinus, northern sea lion Eumetopias jubatus, harbor seal Phoca vitulina richardii, spotted seal Phoca largha, ringed seal Phoca hispida, ribbon seal Phoca fasciata, and bearded seal Erignathus barbatus. Bird species were all those included in Hunt et al. (1981): northern fulmar Fulmarus glacialis, short-tailed and sooty shearwaters Puffinus tenuirostris and $P$. griseus, fork-tailed stormpetrel Oceanodroma furcata, red-faced and pelagic cormorants Phalacrocorax urile and $P$. pelagicus, black-legged and red-legged kittiwakes Rissa tridactyla and $R$. brevirostris, common and thick-billed murres Uria aalge and $U$. lomvia, horned puffin Fratercula corniculata, and tufted puffin Lunda cirrhata.

Total food consumption by pinnipeds was estimated from population sizes and mean body masses listed in Perez (1990) along with the daily energy intake and energy value of the diet from Perez et al. (1990). Northern sea lion abundance estimated on land for 1985 was assumed to be 68000 (Merrick et al. 1987); this estimate was increased by $33 \%$, as suggested by Perez (1990), to account for sea lions away from land. Total food consumption by marine birds was estimated from population sizes, individual bird weights, and residence times in Hunt et al. (1981) and assuming a food consumption rate of $20 \%$ body weight daily.

\section{RESULTS AND DISCUSSION}

\section{Predation by groundfish, marine mammals, and birds}

Estimates of total biomass and number of walleye pollock and Pacific herring consumed by groundfish predators varied with year (Tables $3 \& 4$ ). Removals of pollock and herring by fisheries, pinnipeds and marine birds were estimated using 1985 data for northern fur seal, northern sea lion and fishery removals, and less recent data for bird and other pinniped removals (Table 5). Total estimated removals of pollock and herring were allocated to prey size based on size frequencies eaten by a particular predator (Figs. 4 \& 5). 
Table 3. Theragra chalcogramma and Clupea pallasi. Estimated total biomass of walleye pollock and Pacific herring consumed by groundfish predators in May-September, including walleye pollock cannibalism in October-December, 1985 to 1988 , in the eastern Bering Sea. -: no stomach samples taken

\begin{tabular}{|c|c|c|c|c|c|}
\hline \multirow[t]{2}{*}{ Prey } & \multirow[t]{2}{*}{ Predator } & \multicolumn{4}{|c|}{ Biomass consumed $\left(\mathrm{t} \times 10^{3}\right)$} \\
\hline & & 1985 & 1986 & 1987 & 1988 \\
\hline Walleye & Pacific cod & 201.6 & 368.5 & 240.3 & 316.5 \\
\hline \multirow{7}{*}{ pollock } & Walleye pollock & 3487.1 & 947.9 & 1119.8 & 436.7 \\
\hline & Arrowtooth flounder & 62.4 & 110.9 & 102.0 & 127.9 \\
\hline & Flathead sole & 86.3 & 49.9 & 18.2 & 14.9 \\
\hline & Yellowfin sole & 22.1 & 12.7 & 1.4 & 13.7 \\
\hline & Greenland turbot & 5.3 & 3.9 & 7.3 & 10.8 \\
\hline & Rock sole & - & - & $<1$ & 0 \\
\hline & Total & 3864.8 & 1493.8 & 1489.1 & 920.5 \\
\hline Pacific & Pacific cod & 19.2 & 14.0 & 3.2 & 5.4 \\
\hline \multirow[t]{4}{*}{ herring } & Walleye pollock & 0 & 26.6 & 2.8 & 0 \\
\hline & Arrowtooth flounder & 0 & 3.8 & 6.3 & 0 \\
\hline & Greenland turbot & 0.1 & 0 & 0 & 0 \\
\hline & Total & 19.3 & 44.4 & 12.3 & 5.4 \\
\hline
\end{tabular}

Predation on walleye pollock

Both number and biomass of pollock consumed by groundfish declined from 1985 to 1988 . For individual groundfish predators, consumption varied with year. Walleye pollock, flathead sole Hippoglossoides elassodon, yellowfin sole Pleuronectes asper, arrowtooth flounder Atheresthes stomias, and Pacific cod Gadus macrocephalus consumed age- 0 pollock. Age-1 pollock (approximately 10 to $19 \mathrm{~cm}$ standard length, SL) were consumed mostly by arrowtooth flounder, pollock, and Pacific cod. Pollock cannibalism on age-0 pollock ( $<10 \mathrm{~cm} \mathrm{SL}$ ) dominated estimates of consump- tion by groundfish in terms of both number and biomass for all years.

Groundfish (primarily pollock) were the main source of removals in terms of total biomass and number. Pollock fisheries were the next largest source of removal in terms of biomass, followed by marine mammals and birds. Next in importance after cannibalism for removals in terms of numbers were successively marine birds, marine mammals, and the fishery. Within the marine mammal group, northern fur seals were the largest consumers of pollock. For marine birds, common and thick-billed murres were the main consumers due to their large population size and pollock-eating

Table 4. Theragra chalcogramma and Clupea pallasi. Estimated number (millions) of walleye pollock and Pacific herring consumed by groundfish predators in May-September, including pollock cannibalism in October-December, 1985 to 1988 , in the eastern Bering Sea. Values in parentheses indicate cells with some missing prey size information. -: no stomach samples taken

\begin{tabular}{|c|c|c|c|c|c|}
\hline \multirow[t]{2}{*}{ Prey } & \multirow[t]{2}{*}{ Predator } & \multicolumn{4}{|c|}{ Number consumed (millions) } \\
\hline & & 1985 & 1986 & 1987 & 1988 \\
\hline \multirow{8}{*}{$\begin{array}{l}\text { Walleye } \\
\text { pollock }\end{array}$} & Pacific cod & 6136 & $(10415)$ & 8029 & 6083 \\
\hline & Walleye pollock & $(1016270)$ & $(187619)$ & $(233029)$ & (182215) \\
\hline & Arrowtooth flounder & $(20531)$ & 22766 & $(1600)$ & 5959 \\
\hline & Flathead sole & $(9564)$ & 7078 & 13723 & 1862 \\
\hline & Yellowfin sole & $(10028)$ & $(2408)$ & $(3659)$ & 32244 \\
\hline & Greenland turbot & 172 & 64 & (84) & 294 \\
\hline & Rock sole & - & - & 124 & 0 \\
\hline & Total & 1062701 & 230350 & 260248 & 228657 \\
\hline \multirow{5}{*}{$\begin{array}{l}\text { Pacific } \\
\text { herring }\end{array}$} & Pacific cod & $(305)$ & $(257)$ & $(14)$ & 140 \\
\hline & Walleye pollock & 0 & (306) & $(0)$ & 0 \\
\hline & Arrowtooth flounder & 0 & (12) & 9 & 0 \\
\hline & Greenland turbot & 1 & 0 & 0 & 0 \\
\hline & Total & 306 & 575 & 23 & 140 \\
\hline
\end{tabular}


Table 5. Estimated removals of walleye pollock and Pacific herring from the eastern Bering Sea by fishery, marine mammals, birds and fish using 1985 data where it was available

\begin{tabular}{|c|c|c|c|c|}
\hline \multirow{2}{*}{$\begin{array}{l}\text { Source of } \\
\text { removal }\end{array}$} & \multicolumn{2}{|c|}{ Walleye pollock } & \multicolumn{2}{|c|}{ Pacific herring } \\
\hline & $\begin{array}{l}\text { Estimated } \\
\text { biomass } \\
\text { removed (t) }\end{array}$ & $\begin{array}{c}\text { Estimated } \\
\text { number } \\
\text { removed }\left(\times 10^{6}\right)\end{array}$ & $\begin{array}{l}\text { Estimated } \\
\text { biomass } \\
\text { removed (t) }\end{array}$ & $\begin{array}{c}\text { Estimated } \\
\text { number } \\
\text { removed }\left(\times 10^{6}\right)\end{array}$ \\
\hline Fishery & $1179000^{\circ}$ & $2292^{\circ}$ & $36625^{9}$ & $104^{\mathrm{g}}$ \\
\hline $\begin{array}{l}\text { Marine mammals } \\
\text { Fur seals } \\
\text { Sea lions } \\
\text { Other pinnipeds }\end{array}$ & $\begin{array}{c}257000^{b} \\
137600 \\
56000 \\
63400\end{array}$ & $\begin{array}{l}9568^{c} \\
6744 \\
167 \\
2657\end{array}$ & $\begin{array}{r}18300^{b} \\
0 \\
0 \\
18300\end{array}$ & $\begin{array}{c}161^{\mathrm{h}} \\
0 \\
0 \\
161\end{array}$ \\
\hline Marine birds & $272000^{d}$ & $23706^{e}$ & $906^{1}$ & $30^{1}$ \\
\hline $\begin{array}{l}\text { Marine fish } \\
\text { Walleye pollock } \\
\text { Pacific cod } \\
\text { Other groundfish }\end{array}$ & $\begin{array}{r}3865000^{f} \\
3487000 \\
202000 \\
176000 \\
\end{array}$ & $\begin{array}{r}1062000^{\circ} \\
1016000 \\
6000 \\
41000 \\
\end{array}$ & $\begin{array}{r}19300^{j} \\
0 \\
19200 \\
100 \\
\end{array}$ & $\begin{array}{r}306^{\prime} \\
0 \\
305 \\
1\end{array}$ \\
\hline Total & 5573000 & 1097566 & 75131 & 603 \\
\hline $\begin{array}{l}\text { Exploitable stock } \\
\text { size (age } 3+\text { ) }\end{array}$ & $9426000^{\mathrm{a}}$ & $22217^{\text {a }}$ & $448000^{9}$ & $2416^{9}$ \\
\hline \multicolumn{5}{|c|}{ "Wespestad \& Dawson (1991) } \\
\hline \multicolumn{5}{|c|}{$\begin{array}{l}\text { Total food consumption estimated from energetic values in Perez et al. (1990) and mammal population sizes in Perez } \\
\text { (1990). Diet percentages of walleye pollock and Pacific herring for fur seals and sea lions during } 1985 \text { were taken from } \\
\text { Sinclair (1988) and unpublished data of the National Marine Mammal Laboratory, } 7600 \text { Sand Point Way NE, Seattle, WA } \\
\text { 98115, USA, collected by P. Gearin. Diet percentages of walleye pollock and Pacific herring for other pinnipeds were not } \\
\text { available for } 1985 \text { so long-term averages in Perez (1990) were used }\end{array}$} \\
\hline \multicolumn{5}{|c|}{$\begin{array}{l}\text { 'Estimated for fur seals using the walleye pollock prey size frequency in fur seal stomachs taken in } 1985 \text { reported in Sinclair } \\
\text { (1988). Sea lions were assumed to eat in proportion to the sizes of pollock available (L. Fritz, Alaska Fisheries Science Cen- } \\
\text { ter, Seattle, WA, pers. comm.) so the walleye pollock prey size frequency for sea lions was the combined population size } \\
\text { frequency from the } 1985 \text { bottom and midwater trawl survey in Walters et al. (1988). Size frequency of walleye pollock catch } \\
\text { by other pinnipeds was not available for } 1985 \text { so values reported by Frost \& Lowry (1986) were used }\end{array}$} \\
\hline \multicolumn{5}{|c|}{ 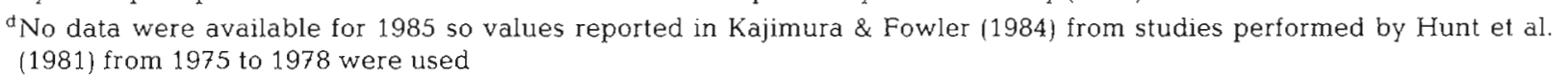 } \\
\hline \multicolumn{5}{|c|}{$\begin{array}{l}\text { ESize frequency of walleye pollock in marine birds was assumed to be the same as those reported for black-legged kitti- } \\
\text { wakes (combined over months) reported by Hunt et al. (1981) }\end{array}$} \\
\hline \multicolumn{5}{|c|}{$\begin{array}{l}\text { 'Includes consumption estimates for all groundfish from May through September and for walleye pollock cannibalism for } \\
\text { May through December }\end{array}$} \\
\hline \multicolumn{5}{|c|}{${ }^{9}$ Wespestad (1991) } \\
\hline \multicolumn{5}{|c|}{${ }^{\mathrm{h}}$ Assuming Pacific herring consumed by pinnipeds were the same sizes as those consumed by Pacific cod in 1985} \\
\hline \multicolumn{5}{|c|}{$\begin{array}{l}\text { 'Assuming Pacific herring was consumed only by common and thick-billed murres on St. Matthew and Hall Islands } \\
\text { (Springer et al. 1986) using diet percentages for } 1983 \text { and assuming a residence period of } 300 \text { and } 330 \text { d, respectively (Hunt } \\
\text { et al. 1981). Assumed average individual weight of Pacific herring consumed was } 30 \mathrm{~g} \text { (Springer et al. 1986) }\end{array}$} \\
\hline 'Estimates of Pacific & nsumption by & sh for the period 1 & gh September & \\
\hline
\end{tabular}

preference. Total removal of pollock biomass is more than half the exploitable (age $3+$ ) stock biomass, while total removal of pollock in terms of number is 2 orders of magnitude greater than the number in the exploitable stock. Consumption of age-0 pollock due to cannibalism was a dominant part of biomass removals but consumption of age-1 (ca 10 to $19 \mathrm{~cm}$ ) fish was more evenly distributed between fish, pinnipeds and birds. Fish, pinnipeds, and the fishery were the primary removers of pollock $>25 \mathrm{~cm}$. Most pollock $>40 \mathrm{~cm}$ were taken by the fishery.
The estimate of pollock biomass consumption by marine mammals was about half that estimated by Kajimura \& Fowler (1984), who used mammal population estimates and estimates of pollock contribution to the diet from pre-1980 data sources. Pinniped populations and the amount of pollock in their diet were larger prior to 1980 , which would explain the higher pollock consumption by mammals during that period. In the present study, mammal population estimates are more up-to-date but only the estimates for fur seal and sea lion predation were actually based on 1985 food 
habits data. Sample sizes and geographic extent of mammal food habits studies tend to be limited and may not always provide reliable estimates of overall diet in a particular year. Marine bird consumption estimates were from the 1975-78 period, during which 2 exceptionally large year classes of pollock were produced. Thus, marine bird consumption of pollock might be overestimated. Consumption of pollock was highest in 1985. This was also the year that had the largest estimated year class size of pollock at age 1 relative to the other years in this study (Table 6). The trawl survey estimate of abundance at age 1 shows that the 1985 year class was at least twice as abundant as the 1986 88 year classes. However, the 1985 year class was only
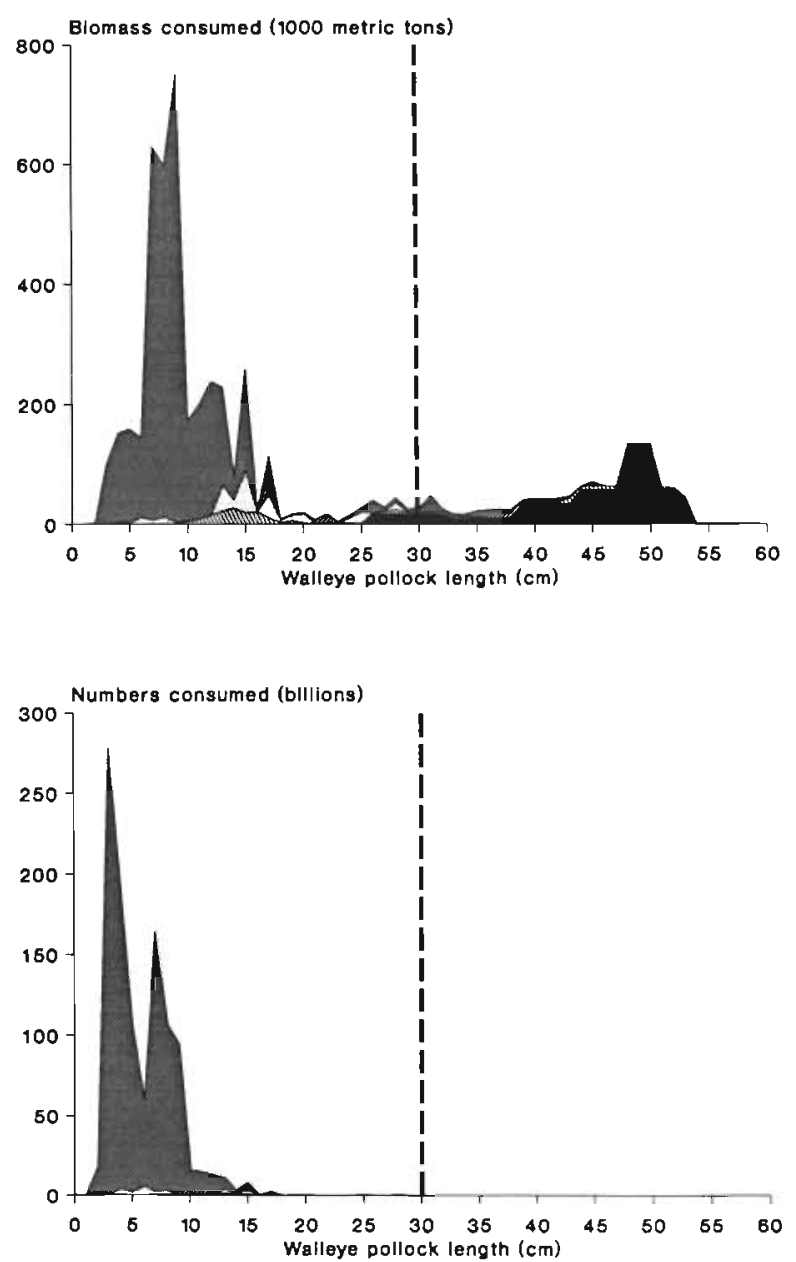

Fishery

Mammals

Birds

Fish

Fig. 4. Theragra chalcogramma. Estimates of biomass and number of walleye pollock taken by the fishery, marine mammals, birds and groundfish on the eastern Bering Sea shelf during 1985. Dashed lines show approximate size at which pollock are fully recruited to the fishery (age 3 )
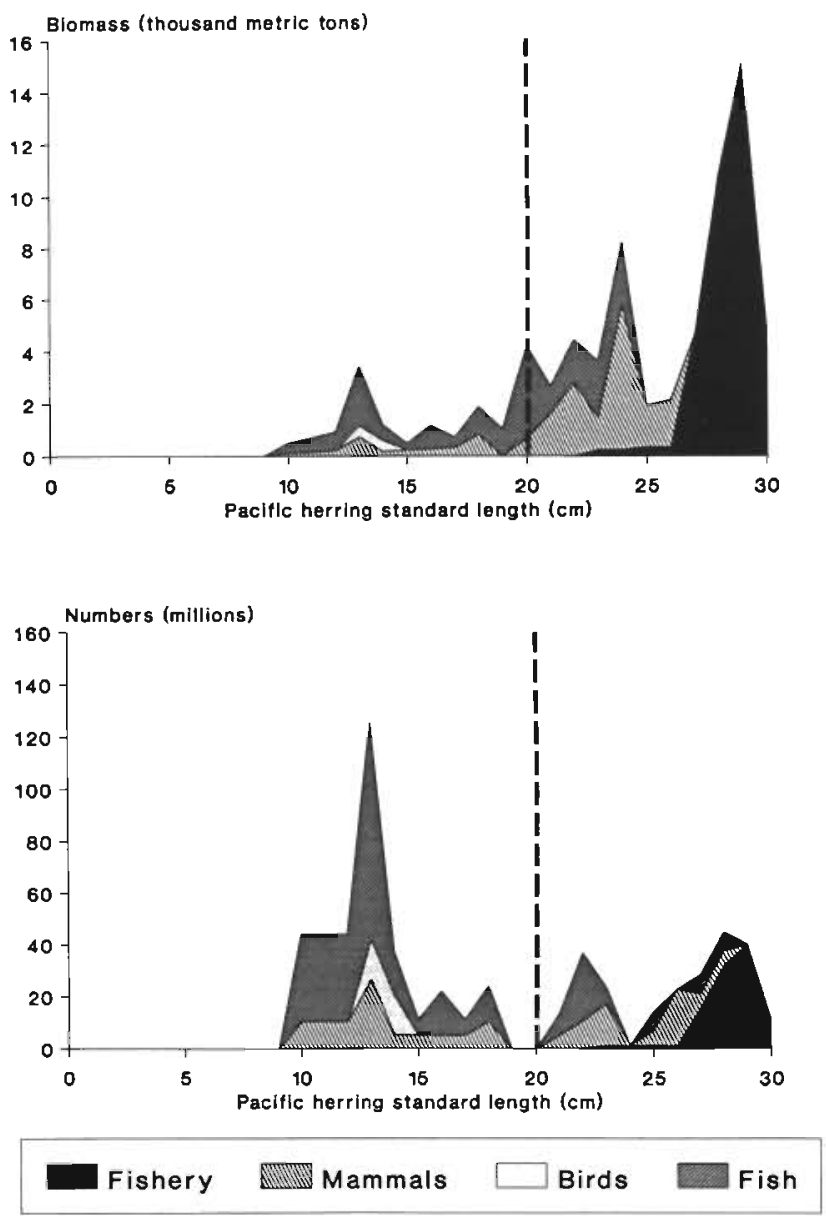

Fig. 5. Clupea pallasi. Estimates of biomass and number of Pacific herring taken by the fishery, marine mammals, birds, and groundfish on the eastern Bering Sea shelf during 1985. Dashed lines show the approximate size at maturity for herring

$25 \%$ more abundant at age 3 than the 1986 year class and was about equal to the 1987 and 1988 year classes at that age (Wespestad \& Dawson 1991). This suggests that some density-dependent process, such as predation, acted to reduce the abundance of the 1985 year class between ages 1 and 3 relative to adjacent year classes.

Estimates of instantaneous predation mortality rates by age for pollock were derived by reconstructing pollock populations at ages 0 to 2 using the method of Forney (1977) and assuming the only mortality suffered was from groundfish predation. It appears that there is interannual variability in mortality rates (Table 7). The most notable feature of variability was that predation mortality rates at age for the 1985 year class were higher than mortality rates for adjacent year classes for ages 0 to 2. (The 1988 year class mortalities could not be estimated without predation data from more recent years.) This supports the idea that preda- 
Table 6 . Theragra chalcogramma. Estimated number of age-0 walleye pollock consumed by groundfish, number of age-1 pollock from the summer bottom trawl survey, and number at age 3 from cohort analysis

\begin{tabular}{|cccc|}
\hline $\begin{array}{c}\text { Year } \\
\text { class }\end{array}$ & $\begin{array}{c}\text { No. eaten } \\
\text { at age } 0 \\
\text { by groundfish } \\
\left(\times 10^{9}\right)\end{array}$ & $\begin{array}{c}\text { No. assessed } \\
\text { at age } 1 \\
\text { (trawl survey) } \\
\left(\times 10^{9}\right)\end{array}$ & $\begin{array}{c}\text { No. assessed } \\
\text { at age } 3 \\
(\text { cohort analysis }) \\
\left(\times 10^{9}\right)\end{array}$ \\
\hline 1985 & 1033.1 & 2.2 & 4.9 \\
1986 & 191.3 & 0.3 & 3.9 \\
1987 & 248.5 & 0.9 & 4.8 \\
1988 & 215.5 & 0.7 & 4.3 \\
\hline
\end{tabular}

Table 7. Theragra chalcogramma. Estimates of annual instantaneous predation mortality rates for walleye pollock based on reconstruction of ages 0 to 2 number assuming groundfish predation as the only mortality source. Predation mortalities for the 1985 year class are underlined. Predation mortalities, including marine mammal and bird predation for 1985, are in parentheses

\begin{tabular}{|ccccc|}
\hline Age & \multicolumn{2}{c}{1985} & 1986 & 1987 \\
\hline 0 & $\underline{3.17}$ & $(2.84)$ & 2.68 & 2.63 \\
1 & 1.25 & $(1.47)$ & $\underline{1.90}$ & 1.13 \\
2 & 0.18 & $(0.33)$ & 0.10 & $\underline{0.31}$ \\
\hline
\end{tabular}

tion was the density-dependent process acting to reduce the relative size of the 1985 year class by age 3 .

This implies that groundfish predators are partially switching to the relatively more abundant 1985 year class for pollock ages 0 to 2 and inflicting higher mortality rates at age than for adjacent year classes. Given. that there is no change in predator abundance, this is a density-dependent response indicative of a type III functional response of predators to changes in prey density (Holling 1959) which produces a mortality rate curve that initially increases as a function of prey density up to a certain maximum and thereafter decreases with further increases in prey density due to 'swamping' of the predator's capacity. This tendency would dampen fluctuations in numbers of pollock recruiting to the fishery at age 3 for prey abundances below the threshold of predator capacity. See Holling (1959) and Peterman \& Gatto (1978) for a description of functional response curves and the associated mortality rate curves. Although the estimated predation mortalities seem high relative to most published rates for adult fish, the rates are reasonable when compared with those for ages 0 to 2 fish derived from multispecies virtual population analysis (MSVPA) (Sparholt 1990, Pope \& Macer 1991).

When marine mammal and bird predation estimates on pollock are used in addition to groundfish predation to reconstruct the size of pollock age classes in 1985 and to calculate instantaneous predation mortality rates, some differences in rates do appear (Table 6). There is a slight decrease in mortality rate for age-0 pollock, a slight increase for age-1, and an almost doubling in the rate for age- 2 pollock. (Note that a decrease in mortality rate at age can occur when adding mammal and bird predation because numbers at age are reconstructed using predation data and mortalities will depend on the relative abundance between adjacent age groups.) Thus, pollock cannibalism dominates the estimates of age-0 mortality rates, but marine mammals, which tend to consume age-1 and older pollock, are important contributors to pollock predation mortality for age-1 and older fish. Unfortunately, there is a lack of a recent time series for marine mammal and bird predation data, which could be used to determine whether they respond in similar ways as groundfish to changes in abundance of particular walleye pollock age classes in the forage base. It seems probable that marine mammals and birds would also exhibit a type III functional feeding response, since this type of response has been shown to occur mainly in vertebrates capable of learning. A type III functional response would lead to compensatory density-dependent predation mortality on pollock by mammals and birds when pollock abundance is increasing.

These results have implications for assessing pollock population size. Currently, most population assessment techniques such as cohort analysis or virtual population analysis assume constant natural mortality rates (which include predation mortality). These techniques usually only consider fish that have already recruited into the fishery. Even multispecies virtual population analysis, which is being used to assess North Sea fish populations (Gislason \& Helgason 1985), tends to assume a type II functional response that produces decreasing predation mortality as a function of increasing prey population size (Hilden 1988). The results from the present study, however, indicate that predation mortality rates at age are not constant and may change in a density-dependent fashion. In particular, when an abundant year class of pollock appears, it seems to be consumed at a higher rate than adjacent year classes. This results in a dampening in the abundance of that year class by age 3 . This may also be true for predation mortality rates of pollock age 3 and older, which have recruited into a fishery. As Fig. 4 suggests, fish and mammal predation on sizes larger than $25 \mathrm{~cm}$ can still constitute an important fraction of removals at that size. Hilden (1988) and Overholtz et al. (1991) have shown that population assessments can change dramatically depending on the underlying assumptions about the nature of predation mortality rates. Including mammal and bird predation 
in such assessments also seems to be important, at least for pollock which is a major prey item for some mammal and bird populations in the eastern Bering Sea.

Unfortunately, although these results indicate the possibility of a density-dependent predation mortality curve, there are insufficient data to estimate the parameters defining the shape of this curve, the exact shape of which may vary from predator to predator and by prey age group. Defining this curve would require more data on predation by mammals, birds, and fish over a longer time series encompassing different levels of pollock abundance.

\section{Predation on Pacific herring}

No trend was apparent in the estimates of total number and biomass of herring consumed by groundfish across the 4 yr period. Pacific cod was the most consistent groundfish predator of herring, consuming mainly age- 1 herring in 3 out of the 4 study years. Pollock consumed herring only during 1986 and 1987, but it had the largest estimated consumption compared to other groundfish predators in 1986. Most herring consumed by groundfish tended to be $<30 \mathrm{~cm}$. Estimates of herring consumed by groundfish were 2 to 4 orders of magnitude less than the estimates of pollock consumed in a given year.

Estimated total removals of herring by fisheries, marine mammals, birds, and fish were much less than losses to the pollock population from these same sources. The fishery was the primary remover of herring biomass. Fish and marine mammals ate approximately equal amounts while birds took the least in terms of biomass. In terms of total numbers, fish removals headed the list followed by marine mammals, the fishery and birds respectively. Harbor seals, ringed seals and spotted seals contributed almost equal amounts to the total consumption by marine mammals. Common and thick-billed murres were the only birds that ate herring. Pacific cod was the main groundfish predator that ate herring during 1985. Total estimated removals relative to exploitable stock size were relatively small.

Most of the herring biomass removed was of fish $>20 \mathrm{~cm}$ (age $3+$ ) with the primary predators being the fishery, pinnipeds and fish. Age-1 (ca 10 to $17 \mathrm{~cm}$ ) fish dominated the number removed and fish, pinnipeds, and birds were the primary predators on this age group.

Consumption of herring by groundfish across years seems to have no clear pattern. There was low correlation $\left(\mathrm{r}^{2}=0.37\right)$ of the total biomass of herring consumed across years by groundfish with biomass estimates of
Table 8. Clupea pallasi. Estimates of total biomass of Pacific herring consumed by groundfish predators and estimates of herring biomass(age $3+$ ) from cohort analysis

\begin{tabular}{|ccc|}
\hline Year & $\begin{array}{r}\text { Total biomass } \\
\text { eaten }\left(\mathrm{t} \times 10^{6}\right)\end{array}$ & $\begin{array}{c}\text { Total biomass } \\
\text { cohort analysis }\left(\mathrm{t} \times 10^{6}\right)\end{array}$ \\
\hline 1985 & 19.3 & 487.5 \\
1986 & 44.4 & 396.7 \\
1987 & 12.3 & 261.6 \\
1988 & 5.4 & 176.5 \\
\hline
\end{tabular}

age $3+$ herring from cohort analysis from Wespestad (1991) (Table 8). Year class abundance estimates for herring at age 5 are available for the 1984-86 year classes (Funk \& Harris 1992), which would have been age 1 in 1985-87, respectively. These estimates indicate that the 1984 and 1986 year classes from the 2 most important herring districts in the eastern Bering Sea were 3 to 5 times more abundant at age 5 than the 1985 year class. This has little relation to the high consumption of the 1984 and 1985 year classes of herring at age 1 by cod during 1985 and 1986 and the absence of the 1986 year class at age 1 in cod stomachs during 1987.

The low correlation of total biomass of herring by eaten by groundfish with biomass estimates of mature herring from cohort analysis is not surprising given some of the life history features of herring in the eastern Bering Sea. Cohort analysis estimates of herring only include estimates of the mature (age $3+$ ) portion of the population while consumption by groundfish was concentrated mainly on herring $<20 \mathrm{~cm}$ or less than age 3. Groundfish predation estimates cover the period of May through September for each year and during this time period mature herring have already moved into inshore waters for spawning (Wespestad 1991). Therefore, only juvenile herring are on the shelf during the main feeding period for groundfish. Juvenile distribution of herring is not well defined; summer bottom trawl surveys show most juveniles in waters less than $50 \mathrm{~m}$ deep, as well as in the northern part of the middle shelf in waters 50 to $100 \mathrm{~m}$ deep (Wespestad 1991). Cod consumption of herring, however, was located throughout the shelf out to bottom depths of $200 \mathrm{~m}$. Consumption of juvenile herring may depend on encounter rates of herring schools rather than overall biomass or numbers. There are insufficient data on groundfish predation on herring during winter when adult herring have moved offshore to winter feeding grounds and there is likely to be more spatial overlap with groundfish predators. Presumably, predators such as cod that are capable of consuming large fish would take advantage of the availability of adult herring during winter. Therefore, 
estimates of herring consumption by groundfish from this study are conservative.

Unlike walleye pollock removals, which were large relative to exploitable stock size, herring removals from all sources in Table 5 were only 17 and $25 \%$ of the exploitable biomass and numbers of herring. This is a likely indication that predation on juvenile herring by groundfish, mammals, and birds during summer periods usually sampled in most food habits studies was not a very important source of mortality from 1985 to 1988 . As discussed in the section on marine mammal consumption of pollock, sample sizes and geographic coverage of marine mammal food habits studies are limited. The estimates of zero herring consumption by fur seals and sea lions are most likely underestimates. Herring may provide a seasonal source of energy for pinnipeds during herring migration periods when pinniped food habits may not be typically sampled. Unfortunately, an updated cohort analysis of herring is not available to provide a starting point for reconstructing age- 2 and age- 1 year class sizes using predation data from this study. Such an analysis would allow the estimation of instantaneous predation mortality rates across years to determine whether density dependent mortality might be occurring.

\section{Ecosystem considerations}

These results show the relative importance of groundfish, mammal, and bird predation on walleye pollock and Pacific herring populations. Predation by adult pollock on age- 0 pollock and by Pacific cod and pinnipeds on age-1 and older pollock was shown to inflict a large amount of mortality that was density-dependent and varied interannually. Similarly, Sissenwine (1986) found adult fish to be the main predator of juvenile fish on Georges Bank. Consumption of herring appeared to be less important, constituting a smaller fraction of the exploitable stock than consumption of pollock. Missing from these calculations were estimates of predation by cetaceans. Lack of quantitative food habits data for cetaceans precluded any projections of their potential consumption, although their population sizes in the eastern Bering Sea (Perez 1990) are high enough that their consumption of pollock or herring could be potentially large. Overholtz et al. (1991) suggest several ways to obtain diet information for cetacean predators. Certainly, much more effort is required to obtain quantitative food habits information on marine mammals and birds on a regular basis in order to fully understand how fluctuations in prey abundance are reflected in their consumption patterns. Even though the present analysis highlights the variability in mortality rates across years, some variability may not be accounted for due to the use of similar assumptions for each sampling year (e.g. constant daily rations and duration of the feeding period).

Although pollock was an important food source for many of these groups, these results cannot be used to make inferences about the effects of changes in pollock or herring abundance on any of these predator populations. Some research indicates the possibility that certain marine fish, such as Atlantic cod Gadus morhua, might not be able to maintain constant energy intake when faced with a decline in a dominant prey species (Lilly 1991). Explanations similar to Lilly's have been put forth to explain the breeding failures in some piscivorous seabirds in the eastern Bering Sea (Springer et al. 1986) and the decline in abundance of northern sea lions (Alverson 1992). Even though the amounts of pollock or herring taken by fisheries may be small proportions of the standing stock in a particular year, little is known about the possible impact fishing may have on marine mammal and bird populations through localized depletions of prey resources near mammal and bird feeding grounds. Also, the longterm impacts of fishery removals are ill-defined. The results from this paper highlight the importance of looking at all potential predators of a prey population because merely comparing removals by one predator group such as mammals or birds with fishery removals would provide a misleading picture of mortality inflicted on a prey population. Furthermore, it is just as important to partition removals by size to show more clearly the relative importance of each predator group in the mortality at age of the prey.

Little is known about the prey preferences and energetics of these predator populations, which would require much more intensive sampling of predators and prey in different areas and time periods. Such samples would allow us to evaluate predator food choices and intake under different environmental conditions and different levels of prey abundance. This would help separate direct environmental effects on predator growth from effects due to changes in prey abundance or prey type.

Acknowledgements. I gratefully acknowledge the efforts of all the members of the Food Habits Program for producing the groundfish food habits data used in this study. Thanks are also extended to Lowell Fritz, Michael Perez, Vidar Wespestad and 3 anonymous reviewers. Their thoughtful and thorough reviews have strengthened and clarified the points made in this paper.

\section{LITERATURE CITED}

Alverson, D. L. (1992). A review of commercial fisheries and the Steller sea lion (Eumetopias jubatus): the conflict arena. Rev. Aquat. Sci. 6: 203-256

Bakkala, R. G., Wilderbuer, T. W. (1990). Yellowfin sole. In: Stock assessment and fishery evaluation document for 
groundfish resources in the Bering Sea/Aleutian Islands region as projected for 1991. North Pacific Fishery Management Council, Anchorage, p. 76-93

Brett, J. R., Groves, T D. D. (1979). Physiological energetics. In: Hoar, W. S., Randall, D. J., Brett, J. R. (eds.) Fish physiology, Vol. VIII: Bioenergetics and growth. Academic Press, New York, p. 279-352

Dwyer, D. A., Bailey, K. M., Livingston, P. A. (1987). Feeding habits and daily ration of walleye pollock (Theragra chalcogramma) in the eastern Bering Sea, with special reference to cannibalism. Can. J. Fish. Aquat. Sci. 44: $1972-1984$

Forney, J. L. (1977). Reconstruction of yellow perch (Perca flavescens) cohorts from examination of (Stizostedion vitreum vitreum) stomachs. J. Fish. Res. Bd Can. 34: 925-932

Frost, K. J., Lowry, L. F. (1986). Sizes of walleye pollock, Theragra chalcogramma, consumed by marine mammals in the Bering Sea. Fish. Bull. U.S. 84: 192-197

Funk, F, Harris, M. (1992). Preliminary forecasts of catch and stock abundance for 1992 Alaska herring fisheries. Regional Information Rep. No. 5J92-04, Alaska Dept. Fish and Game, Juneau

Gislason, H., Helgason, T. (1985). Species interaction in assessment of fish stocks with special application to the North Sea. Dana 5: 1-44

Hilden, M. (1988). Significance of the functional response of predators to changes in prey abundance in multispecies virtual population analysis. Can. J. Fish. Aquat. Sci. 45. $89-96$

Holling, C. S. (1959). The components of predation as revealed by a study of small-mammal predation of the European pine sawfly. Can. Entomol. 91: 293-320

Hunt, G. L. Jr, Burgeson, B., Sanger, G. A. (1981). Feeding ecology of seabirds of the eastern Bering Sea. In: Hood, D. W., Calder, J. A. (eds.) The eastern Bering Sea shelf: oceanography and resources, Vol. 2. Office of Marine Pollution Assessment, Juneau, p. 629-648

Kajimura, H., Fowler, C. W. (1984). Apex predators in the walleye pollock ecosystem in the eastern Bering Sea and Aleutian Islands regions. In: Ito, D. H. (ed.) Proceedings of the workshop on walleye pollock and its ecosystem in the eastern Bering Sea. NOAA Tech. Memo. NMFS F/NWC62: $193-234$

Lilly, G. R. (1991). Interannual variability in predation by cod (Gadus morhua) on capelin (Mallotus villosus) and other prey off southern Labrador and northeastern Newfoundland. ICES mar. Sci. Symp. 193: 133-146

Livingston, P. A. (1989). Key fish species, northern fur seals, Callorhinus ursinus, and fisheries interactions involving walleye pollock, Theragra chalcogramma, in the eastern Bering Sea. J. Fish. Biol. 35(Suppl. A): 179-186

Livingston, P. A. (1991). Methods. In: Livingston, P. A. (ed.) Groundfish food habits and predation on commercially important prey species in the eastern Bering Sea from 1984 to 1986. NOAA Tech. Memo. NMFS F/NWC-207

Livingston, P. A., Dwyer, D. A., Wencker, D. L., Yang, M. S., Lang, G. M. (1986). Trophic interactions of key fish species in the eastern Bering Sea. Int. N. Pac. Fish. Comm. Bull 47: $49-65$

Lowry, L. F., Frost, K. J. (1985). Biological interactions between marine mammals and commercial fisheries in the

This article was submitted to the editor
Bering Sea. In: Beddington, J. R., Beverton, R. J. H., Lavigne, D. M. (eds.) Marine mammals and fisheries. George Allen and Unwin, London, p. 41-61

Merrick, R. M., Loughlin, T R., Calkins, D. G. (1987). Decline in abundance of the northern sea lion (Eumetopias jubatus) in Alaska, 1956-1986. Fish. Bull. U.S. 85: 351-365

Overholtz, W. J., Murawski, S. A., Foster, K. L. (1991). Impact of predatory fish, marine mammals, and seabirds on the pelagic fish ecosystem of the northeastern USA. ICES mar. Sci. Symp. 193: 198-208

Perez, M. A. (1990). Review of marine mammal population and prey information for Bering Sea ecosystem studies. NOAA Tech. Memo. NMFS F/NWC-186

Perez, M. A., McAlister, W. B., Mooney, E. E. (1990). Estimated feeding rate relationship for marine mammals based on captive animal data. NOAA Tech. Memo. NMFS F/NWC-184

Peterman, R. M., Gatto, M. (1978). Estimation of functional responses of predators on juvenile salmon. J. Fish. Res. Bd Can. 35: 797-808

Pope, J. G., Macer, C. T. (1991). Multispecies virtual population analysis of North Sea predators for the years 1963-1987. ICES mar. Sci. Symp. 193: 46-49

Sinclair, E. H. (1988). Feeding habits of northern fur seals (Callorhinus ursinus) in the eastern Bering Sea. M.S. thesis, Oregon State University, Corvallis

Sissenwine, M. P. (1986). Perturbation of a predator-controlled continental shelf ecosystem. In: Sherman, K., Alexander, L. M. (eds.) Variability and management of large marine ecosystems. AAAS Selected Symposium 99 Westview Press, Boulder, p. 55-85

Sparholt, H. (1990). Improved estimates of natural mortality rates of nine commercially important fish species included in the North Sea multispecies VPA model. J. Cons. int. Explor. Mer 46: 211-223

Springer, A. M., Roseneau, D. G., Lloyd, D. S., McRoy, C. P. Murphy, E. C. (1986). Seabird responses to fluctuating prey availability in the eastern Bering Sea. Mar. Ecol. Prog. Ser. 32: $1-12$

Walters, G. E., Teshima, K., Traynor, J. J., Bakkala, R. G., Sassano, J. A., Halliday, K. L., Karp, W. A., Mito, K. I., Williamson, N. J., Smith, D. M. (1988). Distribution, abundance, and biological characteristics of groundfish in the eastern Bering Sea, based on results of the U.S.-Japan triennial bottom trawl and hydroacoustic surveys during May-September, 1985. NOAA Tech. Memo. NMFS F/NWC-154

Wespestad, V. G. (1991). Pacific herring population dynamics, early life history, and recruitment variation relative to eastern Bering Sea oceanographic factors. Ph.D. dissertation, University of Washington, Seattle

Wespestad, V. G., Bakkala, R. G., Dawson, P. (1990). Walleye pollock. In: Stock assessment and fishery evaluation document for groundfish resources in the Bering Sea/Aleutian Islands region as projected for 1991. North Pacific Fishery Management Council, Anchorage, p. 27-50

Wespestad, V. G., Dawson, P. (1991). Walleye pollock. In Stock assessment and fishery evaluation document for groundfish resources in the Bering Sea/Aleutian Islands region as projected for 1992. North Pacific Fishery Management Council, Anchorage, p. 2-27

Manuscript first received: February 1, 1993

Revised version accepted: August 27, 1993 